\title{
PENGARUH LINGKUNGAN KERJA FISIK DAN DISIPLIN KERJA TERHADAP KINERJA PEGAWAI PADA DINAS PENDIDIKAN KABUPATEN ASAHAN
}

\author{
Julius Kwart Siboro \\ Alumni Jurusan Manajemen Fakultas Ekonomi Universitas Negeri Medan \\ Dina Sarah Syahreza \\ Dosen Jurusan Manajemen Fakultas Ekonomi Universitas Negeri Medan
}

\begin{abstract}
Abstrak
Penelitian ini bertujuan untuk mengetahui Pengaruh Lingkungan Kerja Fisik dan Disiplin Kerja Terhadap Kinerja Pegawai pada Dinas Pendidikan Kabupaten Asahan. Penelitian ini dilakukan pada Dinas Pendidikan Kabupaten Asahan dengan jumlah populasi sebanyak 74 orang dengan menggunakan Total Sampling.Teknik pengumpulan data yang digunakan adalah melalui kuesioner yaitu dengan cara menyebarkan kuesioner kepada sampel (responden) dan mengumpulkannya kembali. Teknik analisis data yang digunakan adalah Regresi Linier Berganda.Sebelum data diregresikan maka terlebih dahulu di uji keterkaitannya dengan variabel independen datanya dengan uji normalitas, multikolinearitas, dan heteroskedastisitas.Untuk mengetahui kontribusi factor lingkungan kerja fisik dan disiplin kerja terhadap kinerja pegawai digunakan rumus koefisien determinasi. Diperoleh hasil variabel lingkungan kerja fisik dan disiplin kerja berpengaruh terhadap kinerja pegawai pada Dinas Pendidikan Kabupaten Asahan, dimana nilai $F$ hitung $=34,361>F$ tabel $=3,12$ dengan level of significant $(\alpha) 0,000<$ 0,05. Kesimpulan dari hasil penelitian yaitu terdapat pengaruh yang positif dan signifikan lingkungan kerja fisik dan disiplin kerja terhadap kinerja pegawai pada Dinas Pendidikan Kabupaten Asahan.
\end{abstract}

Kata kunci : Lingkungan Kerja Fisik, Disiplin Kerja, Kinerja Pegawai

\section{PENDAHULUAN}

Pada berbagai bidang khususnya kehidupan dalam instansi milik pemerintah, faktor manusia merupakan masalah utama di setiap kegiatan yang ada didalamnya.Kualitas sumber daya manusia yang baik tentu sangat penting bagi sebuah instansi, hal tersebut kebutuhan yang dominan bagi setiap instansi.Salah satuparameter yang dapat digunakan untukmenilai kualitas SDM adalah kinerja pegawai itu sendiri.Menurut Mangkunegara (2006:7) "Kinerja adalah hasil kerja secara kualitas dan kuantitas yang dicapai oleh seorang pegawai dalam melaksanakan tugas sesuai dengan tanggung jawab yang diberikan kepadanya".Salah satu faktor yang perlu diperhatikan demi terciptanya kinerja yang diharapkan instansi adalah lingkungan kerja fisik.Menurut Komarudin (2007:142) "Lingkungan kerja fisik adalah keseluruhan atau setiap aspek dari gejala fisik yang mengelilingi atau mempengaruhi individu". Lingkungan kerja fisik yang baik akan memberikan rasa nyaman kepada para pegawai dan akan diharapkan menghasilkan kinerja yang baik.

Selain lingkungan kerja fisik, disiplin kerja para pegawai juga dapat mempengaruhi peningkatan kinerja pegawai. Menurut Hasibuan (2010:193) "Kedisplinan adalah kesadaran dan kesediaan seseorang 
menaati semua peraturan perusahaan dan norma-norma sosial yang berlaku". Disiplin kerja yang tinggi akan menunjukkan adanya rasa tanggung jawab yang besar yang dimiliki pegawai dalam menyelesaikan tugas-tugas yang diberikan kepadanya. Salah satu instansi milik pemerintah tersebut yakni Dinas Pendidikan Kabupaten Asahan.Dinas Pendidikan Kabupaten Asahan merupakan salah satu wadah atau instansi resmi yang dimiliki oleh Pemerintah Daerah Kabupaten Asahan.mempunyai masalah dengan disiplin kerjanya.

\section{METODE PENELITIAN \\ Lokasi Penelitian}

Untuk memperoleh data dan keterangan lain, penulis melakukan penelitian pada Dinas Pendidikan Kabupaten Asahan yang beralamat di Jalan Jenderal Ahmad Yani Km.1,3 Kisaran.

\section{Populasi dan Sampel Penelitian}

Menurut Sugiyono (2008:115), "Populasi adalah wilayah generalisasi terdiri atas obyek/subyek yang mempunyai kualitas dan karakteristik tertentu ditetapkan oleh peneliti untuk dipelajari dan kemudian ditarik kesimpulan". Populasi dalam penelitian ini adalah seluruh pegawai yang berada pada Dinas Pendidikan Kabupaten Asahan yang berjumlah 76 orang.Sampel adalah bagian dari populasi yang dapat mewakili populasi sebagai sumber daya penelitian.

Dalam menetapkan sampel penulis berpedoman pada pendapat Riduwan (2005:253) yang mengatakan bahwa: "Apabila subjeknya kurang dari 100, lebih baik diambil semuanya sehingga penelitiannya merupakan penelitian populasi.Selanjutnya, jika subjeknya besar, dapat diambil antara 10-15\% atau $20-25 \%$ atau lebih".

Berdasarkan pendapat diatas, dalam hal ini yang diteliti tidak termasuk Kepala Dinas dan Sekretaris Dinas Pendidikan Kabupaten Asahan. Sehingga sampel dalam penelitian telah di kurangi dengan Kepala Dinas dan Sekretaris Dinas, maka jumlah sampel menjadi 74 dari 76 keseluruhan populasi.

\section{Variabel Penelitian dan Defenisi Operasional Variabel Penelitian}

Dalam pengujian hipotesis, yang menjadi variabel penelitian ini adalah:
a. Variabel bebas (X1) yaitu Lingkungan Kerja Fisik
b. Variabel bebas (X2) yaitu Disiplin Kerja
c. Variabel terikat (Y) yaitu Kinerja Pegawai

\section{Definisi Operasional}

Yang menjadi definisi operasional masing-masing variabel tersebut adalah

a. Lingkungan Kerja Fisik (X1) : Lingkungan kerja fisik adalah segala sesuatu yang ada di sekitar tempat kerja pegawai lebih banyak berfokus pada benda benda dan situasi sekitar tempat kerja sehingga dapat mempengaruhi pegawai dalam melaksanakan tugasnya.

Indikator Lingkungan Kerja Fisik adalah:

1) Kebersihan

2) Penerangan

3) Pertukaran udara 
4) Kebisingan

5) Pewarnaan

6) Peralatan kerja yang tersedia

b. Disiplin Kerja (X2) : Disiplin kerja adalah sikap dan perbuatan pegawai dalam mentaati semua peraturan-peraturan yang telah ditentukan dan harus dipatuhi untuk meningkatkan kinerja di dalam organisasi/instansi.

Indikator Disiplin Kerja adalah:

1) Kehadiran

2) Tata cara kerja

3) Ketaatan pada atasan

4) Kesadaran bekerja

5) Tanggungjawab

c. Kinerja Pegawai (Y) : Kinerja pegawai adalah hasil atau prestasi kerja baik kualitas maupun kuantitas yang dicapai pegawai selama periode waktu tertentu dalam melaksanakan tugasnya yang disertai terpenuhnya standar pelaksana.

Indikator Kinerja Pegawai adalah :

1) Kualitas Kerja

2) Kuantitas Kerja

3) Ketepatan waktu

4) Efektivitas

5) Kemandirian

\section{Teknik Analisis Data}

\section{Analisis Regresi Berganda}

Untuk mengetahui pengaruh lingkungan kerja fisik $\left(\mathrm{X}_{1}\right)$ dan disiplin kerja $\left(\mathrm{X}_{2}\right)$ terhadap kinerja pegawai (Y) pada Dinas Pendidikan Kabupaten Asahan maka peneliti menggunakan teknik analisis regresi berganda (Riduwan, 2007:142) dengan rumus:

Dimana:

$$
\mathbf{Y}=\mathbf{a}+\mathbf{b}_{1} \mathbf{X}_{1}+\mathbf{b}_{2} \mathbf{X}_{2}+\mathbf{e}
$$

Y : Kinerja pegawai

a : Konstanta $\mathrm{b}_{1}, \mathrm{~b}_{2} \quad$ : Koefisien regresi

$\mathrm{X}_{1} \quad$ : Lingkungan kerja fisik

$\mathrm{X}_{2} \quad$ : Disiplin kerja

e : Standar error

\section{Pengujian Hipotesis}

Uji F (Simultan)

Uji $F$ dilakukan untuk membuktikan hipotesis awal tentang pengaruh lingkungan kerja fisik $\left(\mathrm{X}_{1}\right)$ dan disiplin kerja $\left(\mathrm{X}_{2}\right)$ secara bersama-sama sebagai variabel bebas terhadap kinerja pegawai (Y) sebagai variabel terikat dengan rumus sebagai berikut (Sugiyono, 2006:190)

$$
\mathbf{F h}=\frac{\pi^{2} / k}{\left(1-R^{2}\right) /(n-k-1)}
$$

Dimana:

$\mathrm{R}=$ Koefisien korelasi berganda

$\mathrm{K}=$ Jumlah Variabel Independen

$\mathrm{n} \quad=$ Jumlah sampel

Kriterian pengujian hipotesis untuk uji $\mathrm{F}$ adalah:

1) $\mathrm{H}_{0}: \beta_{1}=0$, artinya secara bersama-sama tidak ada pengaruh antara lingkungan kerja fisik $\left(\mathrm{X}_{1}\right)$ dan disiplin kerja $\left(\mathrm{X}_{2}\right)$ terhadap kinerja pegawai $(\mathrm{Y})$.

2) $\mathrm{H}_{\mathrm{a}}: \beta_{1} \neq \beta_{2} \neq 0$, artinya secara bersama-sama ada pengaruh antara lingkungan kerja fisik $\left(\mathrm{X}_{1}\right)$ dan disiplin kerja $\left(\mathrm{X}_{2}\right)$ terhadap kinerja pegawai (Y).

\section{Uji-t (Parsial)}

Uji parsial atau koefisen regresi dimaksud untuk memastikan apabila variabel bebas yang terdapat dalam penelitian tersebut secara individu berpengaruh secara signifikan terhadap nilai variabel terikat.Caranya dengan melakukan pengujian koefisien regresi setiap variabel bebas dengan menggunakan uji t. 
Adapun rumus yang digunakan untuk menguji masingmasing hipotesis adalah dengan uji $\mathrm{t}$ parsial (Riduwan, 2007:125), yaitu:

$$
\mathbf{t}_{\text {hitung }}=\frac{\sqrt[r]{n-2}}{\sqrt{n-r^{2}}}
$$

Penentuan kriteria pengambilan keputusan:

Ho diterima jika $\mathrm{t}$ hitung $<\mathrm{t}$ table pada $\alpha=5 \%$

Ha diterima jika $\mathrm{t}$ hitung $>\mathrm{t}$ table pada $\alpha=5 \%$

\section{Koefisien Determinan (R2)}

Uji ini digunakan untuk melihat kontribusi variabel bebas,yaitu lingkungan kerja fisik $\left(\mathrm{X}_{1}\right)$ dan disiplin kerja $\left(\mathrm{X}_{2}\right)$ terhadap kinerja pegawai (Y). Untuk mengukur uji koefisien determinan dapat digunakan rumus sebagai berikut:

$$
\mathbf{R}^{2}=\frac{b(n \Sigma X 1,2)(\Sigma Y)}{n\left(\Sigma Y^{2}\right)-(\Sigma Y)^{2}}
$$

Pengujian-pengujian di atas dilakukan dengan bantuan program pengolahan data Statistic Packages for Social Science (SPSS) versi 20.

\section{HASIL DAN PEMBAHASAN PENELITIAN \\ Hasil Penelitian \\ Analisis Regresi Berganda}

Untuk menguji hipotesis yang menyatakan terdapat pengaruh Lingkungan Kerja Fisik (X1), Disiplin Kerja (X2) terhadap kinerja pwgawai (Y) digunakan analisis regresi berganda:

$$
\mathbf{Y}=\mathbf{a}+\mathbf{b}_{1} \mathbf{X}_{1}+\mathbf{b}_{2} \mathbf{X}_{2}+\mathbf{e}
$$

Berdasarkan hasil perhitungan diperoleh hasil persamaan regresi ganda adalah sebagai berikut:

\begin{tabular}{|c|c|c|c|}
\hline \multirow[t]{2}{*}{ Model } & \multicolumn{2}{|c|}{$\begin{array}{c}\text { Unstandardized } \\
\text { Coefficients }\end{array}$} & \multirow[t]{2}{*}{ Sig. } \\
\hline & B & Std. Error & \\
\hline (Constant) & 7.567 & 2.958 & .013 \\
\hline $\begin{array}{ll} & \text { Lingkungan } \\
1 & \text { Kerja Fisik (X1) }\end{array}$ & .483 & .090 & .000 \\
\hline $\begin{array}{l}\text { Disiplin Kerja } \\
\text { (X2) }\end{array}$ & .217 & .091 & .019 \\
\hline
\end{tabular}

Tabel 1. Koefisien Regresi Coefficients $^{\mathrm{a}}$

a.Dependent Variabel: Kinerja Pegawai (Y)

Berdasarkan tabel diatas maka dapat dilihat nilai konstanta (nilai a) sebesar 7,567 dan untuk Lingkungan Kerja Fisik (nilai b) sebesar 0,483 serta Disiplin Kerja (nilai b) sebesar 0,217.Sehingga dapat diperoleh persamaan regresinya.

Persamaan regresi tersebut adalah: $Y=7,567+0,483 X_{1}+0,217 X_{2}+e$ Yang berarti:

- Konstanta sebesar 7,567 dapat diartikan bahwa jika tidak ada variabel lingkungan kerja fisik dan disiplin kerja maka nilai kinerja pegawai adalah sebesar 7,567.

- Koefisien regresi variabel X1 sebesar 0,483 menyatakan bahwa kenaikan satu-satuan lingkungan kerja fisik akan meningkatkan kinerja pegawai sebesar 0,483 .

- Koefisien regresi X2 sebesar 0,217 menyatakan bahwa kenaikan satu-satuan disiplin kerja akan meningkatkan kinerja pegawai sebesar 0,217.

\section{Uji Hipotesis \\ Uji Simultan (Uji F)}

Berdasarkan hasil pengujian statistic (Uji ANOVA/Uji F) dapat dilihat pada tabel hasil berikut: 
Tabel 2. Hasil Uji Perhitungan Uji F

\begin{tabular}{|l|c|c|}
\hline Model & F & Sig. \\
\hline $\begin{array}{l}\text { Regression } \\
1\end{array} \begin{array}{l}\text { Residual } \\
\text { Total }\end{array}$ & 34.361 & $.000^{\mathrm{b}}$ \\
\hline
\end{tabular}

Pengujian hipotesis dilakukan

dengan cara membandingkan besarnya angka $F$ pada hasil pengujian dengan Ftabel, dengan kriteria sebagai berikut:

Jika $\mathrm{F}$ hitung $>\mathrm{F}$ tabel, maka Ho ditolak dan Ha diterima

Jika $\mathrm{F}$ hitung $<\mathrm{F}$ tabel, maka Ho diterima dan Ha ditolak

Berdasarkan angka $F$ yang diperoleh dari hasil perhitungan adalah sebesar 34,361. Sedangkan angka $F$ tabel dihitung dengan ketentuan yaitu taraf signifikan 95\% dan alpha 5\% serta derajat kebebasan (dk) dengan ketentuan n-2 = 74-2 = 72 dengan nilai $\mathrm{df}=2$. Dengan ketentuan tersebut diperoleh angka $\mathrm{F}$ tabel sebesar 3,12.

Dengan diperoleh nilai $F$ hitung $=34,361$ dan $\mathrm{F}$ tabel 3,12, maka $\mathrm{F}$ hitung $>\mathrm{F}$ tabel yang berarti bahwa Ho ditolak dan Ha diterima, sehingga dapat disimpulkan bahwa secara simultan terdapat pengaruh antara lingkungan kerja fisik (X1) dan disiplin kerja (X2) terhadap kinerja pegawai (Y)

\section{Uji Parsial (Uji t)}

Uji $t$ dilakukan untuk mengetahui besarnya pengaruh secara parsial tentang variabel lingkungan kerja fisik (X1) dan disiplin kerja (X2) apakah memiliki pengaruh terhadap kinerja pegawai (Y).
Tabel 3. Hasil Uji t Coefficients

\begin{tabular}{|rl|c|r|}
\hline Model & $\mathrm{t}$ & \multicolumn{1}{c|}{ Sig. } \\
\hline & $\begin{array}{l}\text { (Constant) } \\
\text { Lingkungan Kerja }\end{array}$ & 2.559 & .013 \\
1 & $\begin{array}{l}\text { Fisik (X1) } \\
\text { Disiplin Kerja } \\
\text { (X2) }\end{array}$ & 2.356 & .000 \\
& & .019 \\
\hline
\end{tabular}

a.Dependent Variabel: Kinerja Pegawai (Y)

$$
\text { Berdasarkan tabel angka } t
$$

yang diperoleh dari variabel lingkungan kerja fisik (X1) hasil perhitungannya adalah sebesar 5,356. Dengan nilai signifikansi sebesar .000 dan variabel disiplin kerja (X2) hasil perhitungannya adalah sebesar 2,400 dengan nilai signifikansi sebesar .019. Sedangkan angka $\mathrm{t}$ tabel dihitung dengan ketentuan yaitu taraf signifikansi $95 \%$ dan alpha 5\% serta derajat kebebasan (dk) dengan ketentuan n-2 = 74-2 = 72. Dengan ketentuan tersebut diperoleh angka $t$ tabel sebesar 1,666.

Dengan diperolehnya nilai $\mathrm{t}$ hitung $=5,356$ dan $\mathrm{t}$ tabel $=1,666$ maka $\mathrm{t}$ hitung $>\mathrm{t}$ tabel yang berarti bahwa Ho ditolak dan Ha diterima, sehingga dapat disimpulkan bahwa secara parsial terdapat pengaruh yang positif dan signifikan pada lingkungan kerja fisik (X1) terhadap kinerja pegawai $(\mathrm{Y})$.

$$
\text { Kemudian }
$$
dengan diperolehnya nilai $\mathrm{t}$ hitung $=2,400$ dan $\mathrm{t}$ tabel $=1,666$ maka $\mathrm{t}$ hitung $>\mathrm{t}$ tabel yang berarti Ho ditolak dan $\mathrm{Ha}$ diterima, sehingga dapat disimpulkan bahwa secara parsial terdapat pengaruh yang positif dan signifikan pada disiplin kerja (X2) terhadap kinerja pegawai $(\mathrm{Y})$. 


\section{Uji Koefisien Determinasi $\left(\mathbf{R}^{2}\right)$}

Untuk mengetahui seberapa besar persentase pengaruh antara variabel bebas terhadap variabel terikat atau untuk melihat seberapa besar variabel bebas dapat menjelaskan pengaruhnya terhadap variabel terikat. Maka dilakukan pengujian koefisien determinasi $\left(\mathrm{R}^{2}\right)$ sehingga dapat diperoleh hasil seperti tabel di bawah ini:

Tabel 4. Hasil Uji $\mathbf{R}^{2}$ Model Summary

\begin{tabular}{|c|c|c|}
\hline Model & $\mathrm{R}$ & R Square \\
\hline & & \\
\hline 1 & $.701^{\mathrm{a}}$ & .492 \\
\hline
\end{tabular}

a. Predisctors: (Constant), $\mathrm{X}_{2}, \mathrm{X}_{1}$

b. Dependent Variabel: Y

Berdasakan tabel diatas diperoleh nilai dari koefisien determinasi R Square sebesar 0,492. Nilai R Square menunjukkan bahwa variabel bebas mampu menjelaskan pengaruhnya terhadap variabel terikat sebesar 49,2\% atau sebesar 49,2\% variabel lingkungan kerja fisik dan disiplin kerja mampu menjelaskan pengaruhnya terhadap variabel kinerja pegawai. Sisanya sebesar 50,8\% dipengaruhi oleh variabel lain yang tidak dibahas dalam penelitian ini.

\section{PENUTUP}

Berdasarkan hasil penelitian analisis data dengan menggunakan SPSS 20 for windows dan pembahasan hasil penelitian yang telah dikemukakan dan hipotesis pada bab sebelumnya, maka beberapa kesimpulan penting yang dapat diambil dalam penelitian ini, antara lain:

1. Bahwa Lingkungan Kerja Fisik memiliki pengaruh yang positif dan signifikan terhadap kinerja pegawai pada Dinas Pendidikan Kabupaten Asahan.

2. Bahwa Disiplin kerja memiliki pengaruh yang positif dan signifikan terhadap kinerja pegawai pada Dinas Pendidikan Kabupaten Asahan.

3. Secara simultan lingkungan kerja fisik dan disiplin kerja berpengaruh positif dan signifikan terhadap kinerja pegawai dengan uji $\mathrm{F}$ hitung $>$ F tabel yaitu 34,361 $>3,12$.

4. Berdasarkan hasil penelitian terbukti bahwa lingkungan kerja fisik dan disiplin kerja mempunyai pengaruh yang positif dan signifikan terhadap kinerja pegawai dengan koefisien 70,1 dan R Square $49,2 \%$ dan sisanya sebesar $50,8 \%$ dijelaskan oleh factor lain diluar variabel dalam penelitian ini. Selain itu tanda positif pada angka adjust $\mathrm{R}$ Square 0,478 menunjukkan adanya arah yang sama dari ketiga variabel tersebut, artinya semakin tinggi tingkat variabel lingkungan kerja fisik dan disiplin kerja fisik yang terjadi maka kinerja pegawai pada Dinas Pendidikan Kabupaten Asahan akan semakin meningkat.

\section{DAFTAR PUSTAKA}

Antara, I Ketut Kusuma Yogi. 2015. Pengaruh Kepemimpinan, Lingkungan Kerja Fisik, Dan Kompensasi Pada Kinerja Karyawan UD.Terus Di Bali. E-Jurnal Manajemen 
Unud.ISSN:2302-8912. Vol: 4. No: 6. Hal: 1735-1752.

Hasibuan, Malayu SP. 2005.

Manajemen Sumber Daya

Manusia. Jakarta: Bumi

Aksara.

$\begin{array}{rrr} & \text { 2010. } & \text { Manajemen } \\ \text { Sumber } & \text { Daya } & \text { Manusia. } \\ \text { Jakarta: } & & \text { Bumi } \\ \text { Aksara. } & & \end{array}$

K. Widya, Betania; Ade Rustiana. 2014. Pengaruh Lingkungan Kerja Fisik, KepuasanKerja, Dan Disiplin Kerja Terhadap Kinerja

Guru di SMK PGRI 1 Mejobo Kudus. Economic Education Analysis Journal.ISSN.22526544. Volume:3. No:2. Hal:227-231.

Komaruddin. 2007. Ensiklopedia Manajemen. Jakarta: BumiAksara.

Kuncoro, Mudrajad. 2009. Metode Riset Untuk Bisnis dan Ekonomi.Jakarta:

Erlangga.

Lubis,TyaWildanaHapsari. 2015. Pengaruh Motivasi Kerja dan Lingkungan Kerja Fisik Terhadap Kinerja Pegawai Pada Dinas Perkebunan Provinsi Sumatera Utara.Skripsi FE UNIMED

Malthis, Robert I; John H. Jackson.2002.Manajemen Sumber Daya Manusia Edisi I Buku II. Jakarta: PT. Salemba Empat.

Mangkunegara, Prabu Anwar. 2005. Prilaku dan Budaya Organisasi,

Bandung : PT. Refika Aditama.

Mangkunegara, PrabuAnwar . 2006. Manajemen Sumber Daya
Manusia Perusahaan, Bandung: PT. Remaja Rosda Karya.

Manulang, M. 2006. Manajemen Personalia. Aksara Baru. Jakarta.

Moeheriono. 2009. Pengukuran Kinerja Berbasis Kompetensi, Jakarta: Ghalia Indonesia.

Murbijanto, Reinhard Efraim. 2013 Analisis Pengaruh Kompetensi Kerja dan Lingkungan Kerja Fisik Terhadap Kinerja Pegawai (Studi Kasus Pada Pegawai Dinas Tenaga Kerja Kabupaten Bekasi). Skripsi FEB.Undip.

Nuraida, Ida. 2008. Manajemen Administrasi Perkantoran, Jakarta:

Transmedia.

Nurfauziah, Alfi. 2013. Pengaruh Motivasi dan Disiplin Kerja Terhadap

Produktivitas Kerja Karyawan PT.Perkebunan Nusantara IV Kebun Pabatu.Skripsi FE UNIMED.

Resiona, Helena Lence Dacosta Fernandez. 2014. Pengaruh Penempatan, Lingkungan Kerja Fisik dan Motivasi Kerja Terhadap Kinerja Pegawai Negeri Sipil di Lingkungan BAPPEDA Kabupaten Flores Timur. Jurnal Administrasi Publik dan Birokrasi. ISSN:23563885. Vol: 1. No:2. Hal: 7390.

Rivai, Veithzal. 2005. Manajemen Sumber Daya Manusia untuk Perusahaan,dari Teori ke 
Praktik.Jakarta: PT. Raja Grafindo Persada. . 2011. Manajemen Sumber Daya Manusia untuk Perusahaan, dari Teori ke Praktik.Jakarta: PT. Raja Grafindo Persada.

Ridwan. 2005. Rumus dan Data dalam Analisis Statistika. Bandung: Alfabeta. .2007.Rumus dan Data dalam Analisis Statistika.Bandung: Alfabeta. Robbins, P. Stephen. 2006. Perilaku Organisasi. Jakarta: Indeks.

Sedarmayanti.2007. Manajemen Sumber Daya Manusia Reformasi

Birokrasi dan Manajemen Pegawai Negeri Sipil.Bandung: Refika Aditama.

Siagian, Sondang P. 2002. Kiat Meningkatkan Produktivitas Kerja. Jakarta: Cetakan Pertama: PT. Rieneka Cipta.

Siahaan, Suriani. 2015. Pengaruh Insentif dan Disiplin Kerja Terhadap Kinerja Karyawan Pada PT. Bank Perkreditan Rakyat (BPR) Pijer Podi Kekelengen Kantor Cabang Medan. Skripsi FE UNIMED.

Sugiyono. 2008. Memahami Penelitian Kualitatif. Bandung: Alfabeta.

Sumarsono. 2004. Metode Riset Sumber Daya Manusia. Yogyakarta: Graha Ilmu

Suseno, Vyo Sandra; Miftahul Munir. 2013. Pengaruh Lingkungan Kerja Terhadap Produktivitas Kerja Karyawan Bagian Produksi Bidang Sanggan (Studi Kasus Pada PT. Gudang Garam Tbk.).
Jurnal Cendekia. ISSN:16936094. Vol: 11. No: 2. Hal: 5867.

Vijaya, I Dewa Gede Ngurah Eka Tvam; A.A. Ayu Sriathi.2015.Pengaruh Kepemimpinan Transformasional, Lingkungan Kerja Fisik dan Kompensasi Terhadap Kinerja Karyawan Pada Perusahaan Cok Konfeksi Denpasar. EJurnal Manajemen Unud. ISSN:2302-8912. Vol: 4. No: 7. Hal: 1845-1864. 